Anarchiving the New York Avant-Garde: The Phantom of Barbara Rubin's Christmas on Earth

Giulia Rho

DOI:10.15664/fcj.v19i0.2389

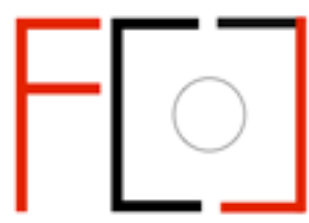

Frames Cinema Journal ISSN 2053-8812

Issue 19 (March 2022)

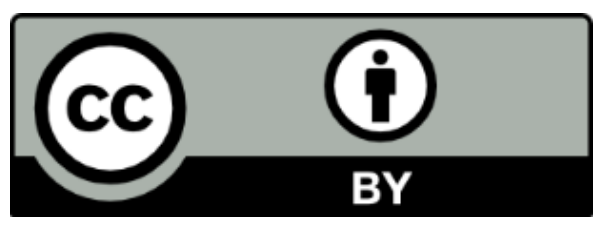




\section{Anarchiving the New York Avant-Garde: The Phantom of Barbara Rubin's Christmas on Earth}

Giulia Rho

Barbara Rubin's Christmas on Earth (1963-1965) is one of the most transgressive and provocative films of the North American avant-garde. Just a seventeen-year-old "woman with a movie camera", Rubin shot the film on a $16 \mathrm{~mm}$ Bell and Howell borrowed from none other than Jonas Mekas, the "midwife", in his own words, of the New York avant-garde. ${ }^{1}$ The 20minute short film is considered "one of the most sexually explicit, beautifully hallucinatory films to come out of the $1960 \mathrm{~s}$ " as it powerfully conveys the inexhaustible romanticism, physical experimentation and cultural desires of the era. ${ }^{2}$ Filmed over just a few days, at a drug-fuelled party in John Cale and Tony Conrad's New York City apartment, it features three men and one or possibly two women engaged in various acts of lovemaking. ${ }^{3}$ The film's psychedelic editing was further complicated by Rubin's instructions for its screening, which involved two layered reels, coloured gels of the projectionists' preference, and also the projectionist's choice of live rock radio "played loud", so that the audience's experience was never twice the same. ${ }^{4}$

In this featurette, I employ the methodology of anarchiving as devised by Brian Massumi and Erin Manning, which considers the archive as "a repertory of traces [that are] carriers of potential. They are reactivatable, and their reactivation helps trigger a new event which continues the creative process from which they came, but in a new iteration." 5 Through it, I interrogate the significance of Rubin's contribution to the American avant-garde, anarchiving Christmas on Earth by examining its dissident potential. Because the anarchive refers to the innate unruliness of the archive in the digital age and its constant variation through encounters, I reflect on how the event of watching Christmas on Earth lets the film "loose to proliferate 
through networks, mutating as [it] goes, and triggering follow-on events." ${ }^{\prime \prime}$ Finally, reading Rubin's work as a process of becoming, I question the spectral status of her legacy.

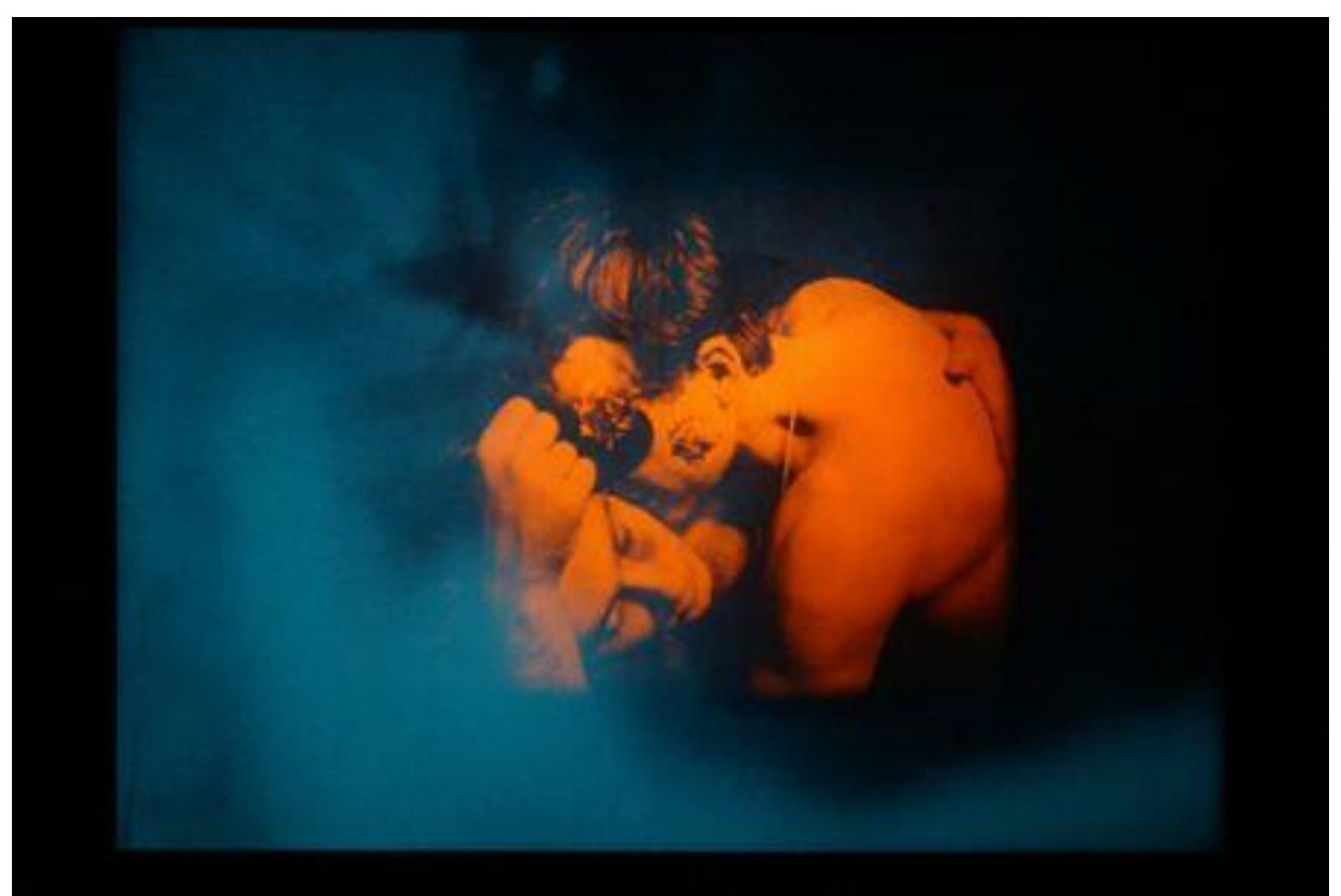

Figure 1: Christmas on Earth (Rubin, 1963-65). Courtesy of The New American Cinema Group, Inc./The FilmMakers' Cooperative

Rubin is a ghost in the archives: only Christmas on Earth fully survives of her works and biographical references are scattered in the testimonies of the many characters she drew to herself in the 1960s, including Bob Dylan and Andy Warhol. ${ }^{7}$ These fragmented references, according to Ara Osterweil, are "proof that she existed, but also evidence of how she disappeared". ${ }^{8}$ Overshadowed in the male-dominated milieu in which she operated, Rubin's legacy has for the most part gone unrecorded and it is hard not to think that the surviving documents attest to a loss more than a fully realised presence. As So Mayer writes: "these traces $[\ldots]$ are separated out from a living artistic culture. [...] Their visibility amid scarcity creates an ambiguous image, where it's hard not to see them as evidence of loss, rather than 
engage with the fullness of their presence". 9 It is indeed difficult not to draw a connection between the nature of Rubin's work and the scarcity of its availability.

In 2019, Rubin seemed for a moment to finally get her due. The documentary Barbara Rubin and the Exploding NY Underground by scholar and director Chuck Smith recounts Rubin's troubled life and bold artistic pursuits through the testimonies of Jonas Mekas, film critic Amy Taubin and some of Rubin's relatives and friends. Despite being made for an audience larger than the fans of avant-garde cinema, who would not need the background information on Warhol's Factory, Allen Ginsberg and the Filmmakers' Co-Op the documentary zealously provides, the film is a compelling portrait of the artist as a young woman. Rubin is nonetheless heavily mediated by impressions and memories, overshadowed by boy geniuses such as Bob Dylan and Lou Reed who receive more attention than Christmas on Earth. What is most fascinating about the documentary is the fate it has suffered. Having been originally released on DVD and made available for streaming rental on Amazon, it vanished from Prime video in August 2020. In an interview, Smith explained that the film had received complaints for its "pornographic content", and Amazon had decided to make streaming unavailable. ${ }^{10}$ The ghost of Barbara Rubin is still fighting the same battles she was in 1964 when she wrote: "do not baby the people. [...] Let all art be free. Let all life expressions be free". ${ }^{11}$ More recently, Barbara Rubin's image appears in Todd Hayne's documentary The Velvet Underground (2021), and she is mentioned in passing for having introduced the band members to Andy Warhol. Rubin is constructed as a marginal character, and her crucial role in the scene is grossly understated, portraying her as an eccentric groupie. The documentary makes no mention of her own artistic production.

Partly at fault for Christmas on Earth's invisibility is the refusal of a feminist label, although Rubin embodied the quest for liberation and self-determination of many young women her 
contemporaries, as Joyce Johnson recounts in her Beat Generation memoir Minor Characters. ${ }^{12}$ "Barbara, like Maya Deren", remembers Taubin, “didn't have any way to articulate that they were feminists. It was inchoate, their sense of, 'oh, there's patriarchy and it makes us feel bad, or inferior.' I mean it was even more inchoate than that". ${ }^{13}$ Had Rubin survived long enough, she would have perhaps found the home she craved in the radical feminism of the 1970s. Her aspirations towards the body and its representation were deeply anarchic: Christmas on Earth polemically asserts the multiplicity and freedom of the human body, de-essentialising the flesh through a fantastical ever-changing metamorphosis. The film could be best classified as queer cinema when considering the radical artistic and sexual vision it enacts, offering an erotic utopia that exceeds the "then and there" - to borrow José Esteban Muñoz phrase- of the 1960s. ${ }^{14}$ Rubin herself, despite eventually marrying and having children as part of her Hasidic conversion, loved and lived with queer men and women, performing a fluid sexual identity. Just like its maker, Christmas on Earth is in a constant state of becoming.

Christmas on Earth pushed the boundaries of the representation of the male and female nude, especially of the depiction of sexual acts on screen, and pioneered hallucinatory editing techniques such as the blinking format or double exposure. More explicit than its better-known contemporaries, Kenneth Anger's Scorpio Rising (1963) and Jack Smith's Flaming Creatures (1963), Christmas on Earth neither suffered nor benefited from the same level of censorship or reputation, despite Rubin' best efforts to screen it illegally at the most inopportune venues and times. ${ }^{15}$ Yet Christmas on Earth remains "one of the most compelling testaments to the spirit of experimental cinema of the 1960s and the counterculture, as well as a work of unparalleled formal and aesthetic consequence", despite seldom being referenced by authors interested in the movement and receiving only a quick mention in David E. James' seminal Allegories of Cinema. ${ }^{16}$ A film as famed as it is invisible - although its fate might be about to change. 
The original print of Christmas on Earth preserved at the Filmmakers Co-op in New York City was recently digitised and made available for rental, but the opportunity to stream it added up to about 200 USD - a prohibitive price for personal viewing. The decision was apparently not without controversy. Taubin criticized the arrangement of separate reels into one digital file, which froze the film into a definitive form rather than leaving the images to interact differently depending on exhibition circumstances. ${ }^{17}$ The same argument was made for the choice to add a set soundtrack of music by The Velvet Underground and other bands associated with the scene, which again deprived the film of its characteristically free-form nature. ${ }^{18}$

This immaterial version of the film was soon crystalised and democratised when it appeared on an illegal streaming website free of charge. The digital ghost of Christmas on Earth is now a runaway document rebelling from official histories of the New York avant-garde, which seem to neglect the importance of Rubin. It reclaims the leftovers of her legacy and carves out the "intangible anarchivic materialities of the doing, thinking, feeling, touching vibrations [that] do resonate in the folds of whatever it ends up being". ${ }^{19}$ Digital files are undoubtedly easier to watch and show, but the loss of the material components of such an interactive film implies a degree of mourning for the absent body of the reels, the gels, the radio. The physical connection with Christmas on Earth in its online archival format becomes then between the body of the audience and those of the performers, distant in time but sensually evoked in the experience of viewership so that nothing of the original intent is truly missing. The low resolution, digitised version of the film actualises Gilles Deleuze's idea that one must subtract to compose well as it loses in materiality, but peaks in the coming together of a hauntingly erotic encounter in which the affects unfolding from the film combine with the power of the bodies of the audience, giving rise to unpredictable and collaborative articulations of meaning. ${ }^{20}$ 
The film emerged from dynamic interactions with the footage, as it was spontaneously shot, edited, and re-edited for each performance. The method behind the fragmentation of the material is unconventional: Rubin, high on amphetamines "absently enchanted" spent months cutting up the film strips and throwing them in a basket, to then put them back together randomly to create two different reels, one half the size of the other. ${ }^{21}$ If the impulsiveness of the editing comes through in the film's whirlwind rhythm and its speed, it is nonetheless evident that the two reels, Reel A and Reel B, are composed of a somewhat consistent themes, identifiable if one watches the reels individually.

Reel A privileges fragmented bodies and details, delivering extreme close-ups of vaginas, mouths, anuses, and male genitalia. The camera's unashamed look brings the spectator so close to the actors' bodies that one feels almost swallowed by the action. Reel B, by contrast, features more complete bodies and group shots. The performers are covered in extravagant make-up and veils and are indistinguishable and unrecognisable. The female character is slathered almost completely in what looks like black paint in the black-and-white film, apart from her breasts and belly which remain "negative" spaces and take on the appearance of a grotesque mask. The masquerade element of Christmas on Earth powerfully situates the events in an exotic fantasy setting, transforming the sexual acts into primitive and esoteric rituals. The eccentricity of the film's content and form functions to estrange the spectators from the taboos of bourgeoise society and to surrender to the hypnotic and shocking beauty of the human body. 


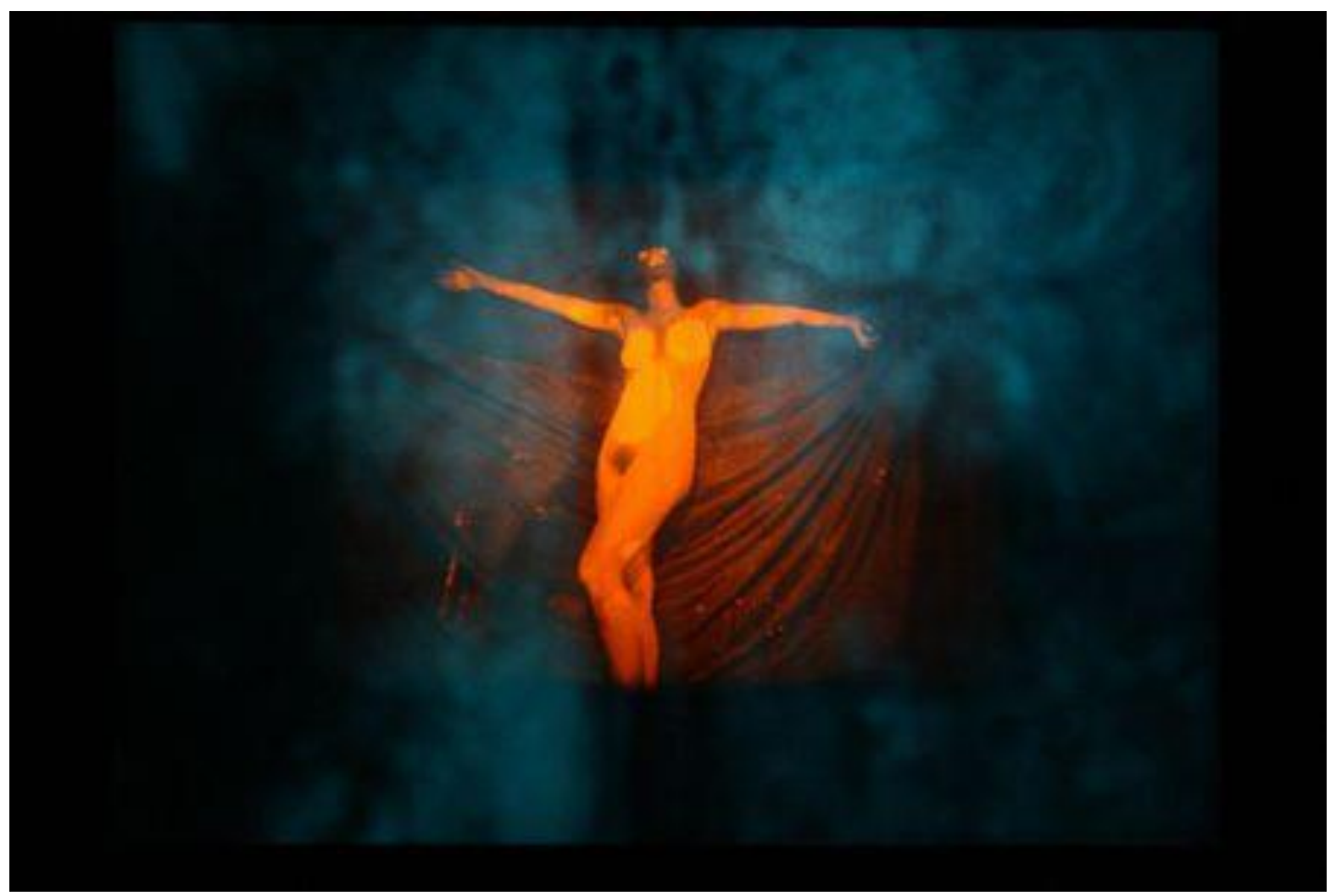

Figure 2: Still from Christmas on Earth (Barbara Rubin, 1963-65) showing the female character's body paint. Courtesy of The New American Cinema Group, Inc./The Film-Makers' Cooperative

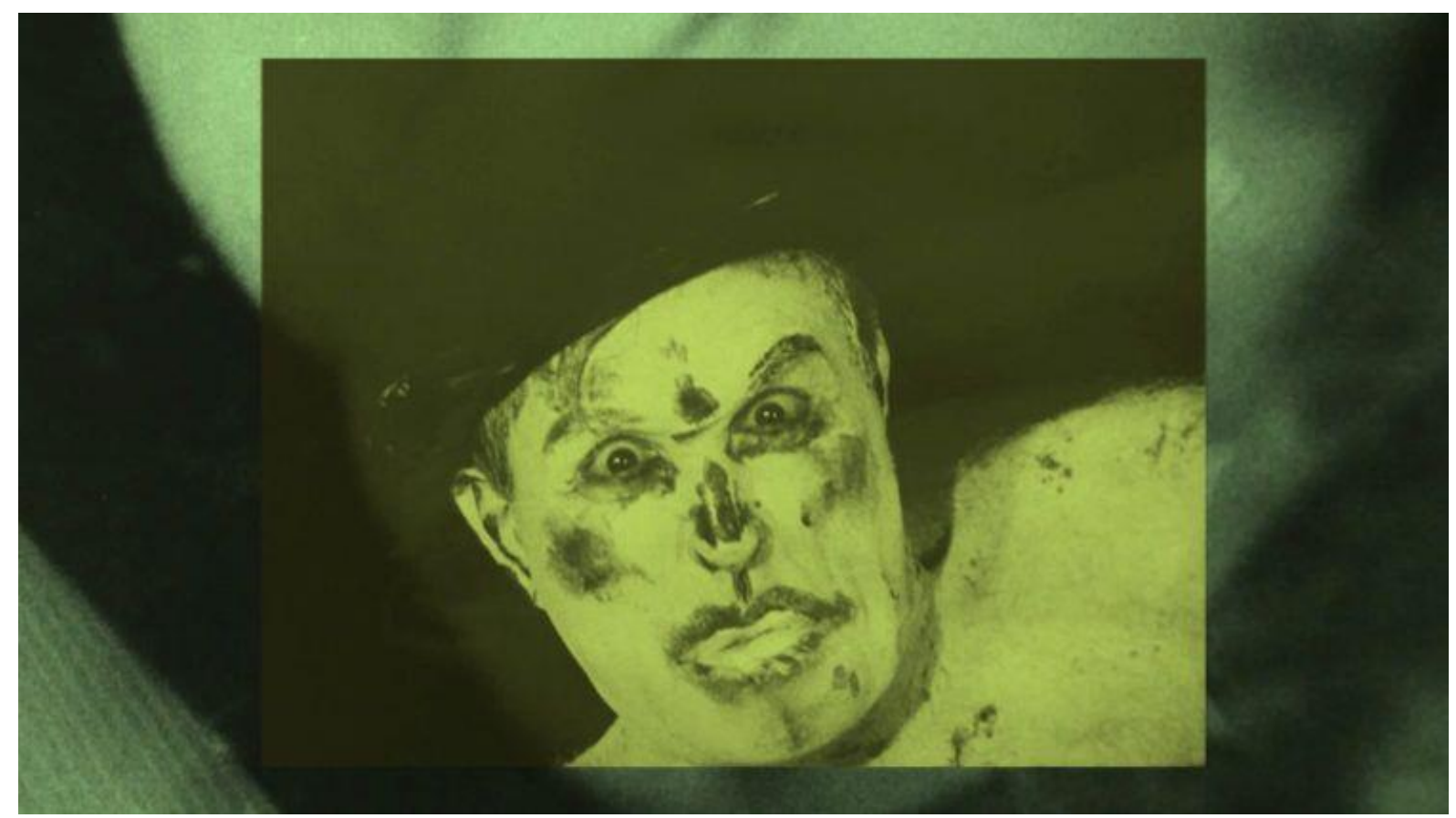

Figure 3: Still from Christmas on Earth (Rubin, 1963-65) showing one of the male character's make-up. Courtesy of The New American Cinema Group, Inc./The Film-Makers' Cooperative. 
In Christmas on Earth, faces overlap with genitalia, limbs become entangled and indistinguishable, and couples penetrate every orifice. While Reel B records specific, real time sexual encounters, Reel A abstracts the flesh to create a hallucinatory spectacle. The film's extraordinary visual pleasure exceeds the boundary of male and female, subject and object, documentary and performance and mirrors the contingent, excessive and joyful quality of the love-making event. The intermingling that happens through the superimposed projection of two different reels of unequal size is the key formal innovation of the film. Through this optical effect, whereby bodies transcend spatial and temporal boundaries, surrender their unitary identity and constantly become-other and immaterial in the extreme abstraction of the closeup, the audience is "moved towards a sense of love's limitlessness". ${ }^{22}$ The two reels produce a "kinesthetic frisson" which gives way to an erotic dialectic. ${ }^{23}$ The film's frame-within-a-frame format reimagines the possibilities for penetration, as noted by scholars Sally Banes and David James $^{24}$. Osterweil furthers this argument by considering the frenzied camera movements and the thrusting motion that mimics the viewers' immersion in the on-screen sexual acts. ${ }^{25} \mathrm{I}$ would add to her analysis the haptic quality of Christmas on Earth, which paired with the fragmentation and multiplication of images of the body, contributes to Rubin's intention of expanding the viewers' thoughts to encompass the experience of both the surface and the depth of the performers' bodies. 


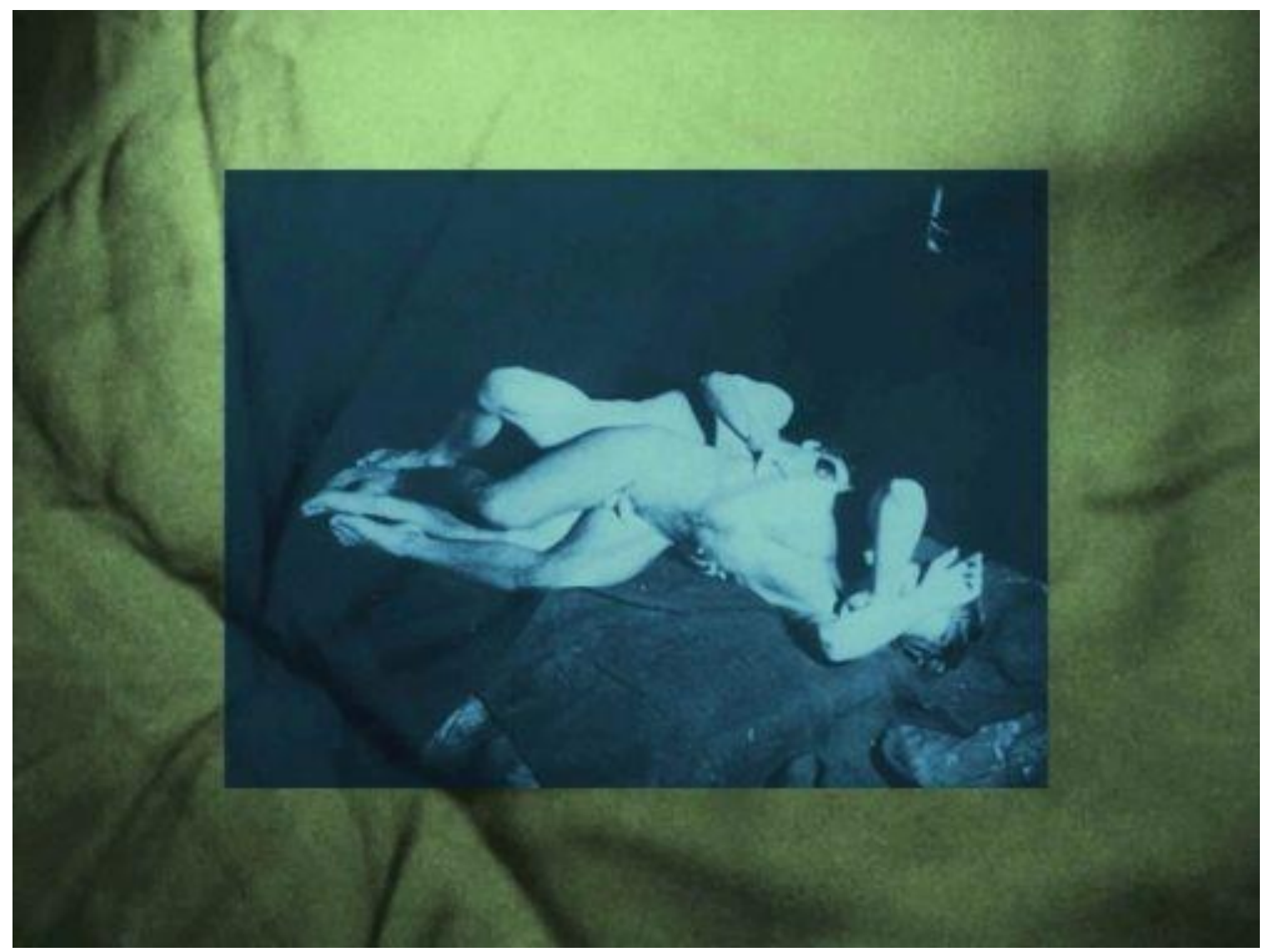

Figure 4: Still from Christmas on Earth (Rubin, 1963-65) of layered Reel A, a detail close-up, and Reel B a group shot. Courtesy of The New American Cinema Group, Inc./The Film-Makers' Cooperative

The subjective exchange that derives from watching Christmas on Earth simulates the sensation of being haunted, as the audience's emotional and physical boundaries are breeched, and they experience the moment in communion with another whom they have never met. The erotic quality of Christmas on Earth derives therefore not only from its obvious sexual content, but from its formal design too. The visual style requires the spectator to surrender control and to experience desire and pleasure along with the performers rather than for them as objects. Individual distinctions are muddled by Rubin's superimpositions and swinging camera movements, so that while the characters remain unknowable, the spectators delight in the overwhelming sensorium of alterity. The film is doubly intimate: on one hand it offers an erotic textual experience, in which the penetrative reciprocity shatters the audience's sense of self and allows for the emergence of a "ghost", here meaning the unfulfilled possibility of Rubin's legacy and her intention to dispel sexual taboos. On the other, engaging with the film in its 
online form is a flirtation, a romance with the "spectral messianicity" of the digital archive which directs desire towards actualising forgotten histories and participating in a connection that will liberate images from silence and place them in a constellation with the viewers' preexisting knowledge. ${ }^{26}$ Such duplicity confirms Christmas on Earth's status as an anarchive, because the film is a "feed-forward mechanism for lines of creative process, under continuing variation". ${ }^{19}$ The digital version furthers the process of improvisation that Rubin intended for her screenings, making itself available to infinite audiences and in a myriad of locations. Watching the film in this format, albeit deviating from the original projection instructions, becomes a "militantly melancholic practice that struggles against amnesiac history", a productive nostalgia that ignites a renewed curiosity for Rubin's intents. ${ }^{27}$

Rubin constructed the "fantastical, Orientalist sexual space" in which the action takes place as a 1960s wonderland in which dichotomies cease to exist and gender roles collapse. ${ }^{28}$ The men in Christmas on Earth are relieved of the pornographic mandate that the male orgasm should be the ultimate teleological impulse. The film insists on the continuity instead of the ending of sexual pleasure implied by orgasm, and recasts male sexual climax as only one possibility of bodily ecstasy. Christmas on Earth features several sequences of male genitalia undergoing transformations, from swelling erections to relaxed stasis and even a penis being hidden behind one of the performer's scrotum, only to return into view a few seconds later. These images denounce masculinity as a form of masquerade just as constructed as femininity and question the traditional portrayal of male bodies. Furthermore, the representation of homosexual coupling as well as heterosexual acts implies a kind of unthreatening and celebratory bisexuality and positions men's bodies as available for penetration too. The relations structured by anatomical difference are discounted and prescribed sexual roles collapse in a pervasive desire of being spread and occupied, of being made multiple and more than oneself. It is also important to note that throughout the film sexuality is never associated with violence or 
discomfort. Rather, the "polymorphous pleasures of eccentric embodiment" are enjoyed consensually and enthusiastically. ${ }^{29}$

The uninhibited expression of sexual desire at play in Christmas on Earth attempts to shed the constraints of erotic taboos, imagining a "sexual utopia, unpolluted by the political economy of the present". ${ }^{30}$ In its treatment of multifaced interactions and blurred identities, the film asserts the triumph of plurality and alterity over the phallomorphism of both mainstream cinema and the underground scene of New York in the 1960s. It critiques and furthers the formal experiments of the American avant-garde, contributing a young woman's perspective, and challenges the viewer to welcome the repressed. It is no surprise then that "the silence surrounding Christmas on Earth is at once appropriate and appalling, for the film more than delivers on the promise... of its wonderful title". ${ }^{31}$ The teenage babushka "angel of Love", Barbara Rubin was committed to eradicating the same censorship that has obscured the significance of her contribution to the New York art scene. ${ }^{32}$

Nevertheless, she pervades scholarship and pop culture alike in absentia, so that forgetting her only leaves traces of her presence. Her image haunts the memory of the men she supported, infecting all those around her with a feverish sensation that there is somebody to be remembered, a symptom of Derrida's mal d'archive, translated by So Mayer as "the phantom ache of the lost limb, the history that can be accessed only through its absence". ${ }^{33}$ Barbara Rubin, like a true "wretched of the screen", disrupts the persistence of vision so that we witness at once the existence of alternative histories and their erasure. ${ }^{34}$

The fragments that make up Rubin's legacy constitute a repertoire of traces which survives as an anarchive, a surplus-value testimony of the official histories of the New York underground. 
Albeit existing in the interstice of memory, Rubin and her art are not inert, but rather are reactivatable. They "serve as a springboard" because they are "compositional forces seeking a new taking-form; lures for further process". ${ }^{35}$ Seeking out Christmas on Earth disturbs the established archive through a desire to look for what has been obscured, as it reactivates traces in an anarchival process of research-creation: reclaiming erased histories is not only an act of resistance, but of becoming differently in light of what has been learnt. Encountering the ghost of Rubin and loving her disappearing image invites us into a physical collaboration with her work. The radical sensuousness of her art is constantly remade through the spectators, so that our "collective sensory experience respond[s] to the exile" of her memory, closing the distance in space and time that separates us from her by completing the filmic event in our bodies. ${ }^{36}$ Perhaps Christmas on Earth has been an anarchive from its inception, because "anything that structures the potential for feeling - and thus action, remembering, thinking - could be thought of as an anarchive" and the film is about possible actions and visions for the future, a time to come not-yet-here as its title suggests. ${ }^{37}$

Today, Christmas on Earth conjures an alternative history within easily accessible archival film collections, and to view it is a "process of deviation from the ordered, of the seeking for the new within or around the old". ${ }^{38}$ The inevitable melancholia derived from watching a lowresolution copy of Christmas on Earth available illegally online is a perpetual mourning for a loss of visual plenitude and for the contingencies of live screenings, but also a call to action that reaches out across time. Witnessing the disappearance of images with which we identify our most vulnerable identities gives us a sense of our own possible erasure because, in the words of Laura U. Marks: "cinema disappears as we watch, and indeed as we do not watch". 39 This leads one to wonder whether it is not the film's inconsequentiality that has led to its silencing, but rather the dangerous energy it contains. The persistent ache that occupies the empty space of the lost object can give us a clue: attending to the phantom of Barbara Rubin, 
there is a feeling of possibility that something is still virtual and waiting to be actualised. The experience of watching Christmas on Earth and losing oneself to its psychedelic pleasures is a beginning, an early unmasking of the hegemonic notions of identity and the stereotypes it maintains. While many have dismissed Rubin's apocryphal career for her young age and the unique performance of her vision of art as community, it would be a mistake not to allow her to queer our understanding of the New York avant-garde. Engaging with her legacy and liberating Christmas on Earth from the interstice of forgetting is to give in to the same ardent yearning the film awakes in us and to release the force of Rubin's imaginary by putting it in contact with viewer's own dissident potential.

\section{Notes}

\footnotetext{
${ }^{1}$ Ara Osterweil, “Absently Enchanted," in Women's Experimental Cinema, ed. Robin Blaetz (Durham, DC: Duke University Press, 2007), 127; Jonas Mekas, Movie Journal: The Rise of a New American Cinema, 1959 - 1971 (New York: Macmillan, 1972), ix.

${ }^{2}$ Osterweil, "Absently Enchanted", 128.

${ }^{3}$ John Cale (b. 1942) is a musician, member of The Dream Syndicate in the early 1960s, then of The Theater of Eternal Music with Tony Conrad, and eventually of The Velvet Underground. Tony Conrad (1940 - 2016) was a musician and structuralist video artist member of The Theater of Eternal Music with John Cale. Recognizable performers in Christmas on Earth include Gerard Malanga (b. 1943), American poet, photographer, filmmaker and archivist, and Barbara Rubin's friend Debra Feiner Coddington.

${ }^{4}$ Barbara Rubin, "Christmas on Earth [Projection Instructions for her film Christmas on Earth, ca. 1965]" in Film Culture 80, ed. Jonas Mekas and Chuck Smith (Leipzig: Specter Books, 2018), 163. ${ }^{5}$ Brian Massumi, "Working Principles" in The Go-To How-To Book of Anarchiving, ed. Andrew Murphie (Montreal: The SenseLab, 2016), 6.

${ }^{6}$ Leslie Plumb, “Immediations Partnership Grant Proposal, 2013”, accessed January 31 2022. http://leslieplumb.com/webdev-front.html

${ }^{7}$ Barbara Rubin appears for example on the back cover of Bob Dylan's record Bringing it All Back Home (1965), in Andy Warhol's film Screen Test [st286] (1965), in Jonas Mekas' Walden (1964-9). Most recently her photos were featured in Todd Haynes's documentary The Velvet Underground (2021), and testimonies in the film briefly mentioned her contribution to the band's climb to fame and iconic aesthetics.

${ }^{8}$ Ara Osterweil, Flesh Cinema: The Corporeal Turn in American Avant-Garde Film (Manchester: Manchester University Press, 2014), 27.

${ }^{9}$ So Mayer, A Nazi Word for a Nazi Thing (London: Peninsula Press, 2020), 95.

${ }^{10}$ Fisher, "Her Incantatory Voice", 4.

${ }^{11}$ Barbara Rubin, "Co-Op Declaration", May 23, 1964. The Barbara Rubin Papers, \#8612. Division of Rare and Manuscript Collections, Cornell University Library, Ithaca, NY.

${ }^{12}$ Joyce Johnson, Minor Characters (London: Methuen Publishing Ltd, 1983).

${ }^{13}$ Amy Taubin, "She Picked Up a Camera and Decided to be a Filmmaker. Amy Taubin on Barbara Rubin" in Film Culture 80, ed. Jonas Mekas and Chuck Smith (Leipzig: Specter Books, 2018), 48-9.
} 
${ }^{14}$ José Esteban Muñoz, Cruising Utopian, The Then and There of Queer Futurity (New York: New York University Press, 2009). For a reading of Christmas on Earth's soundtrack through Queer Theory see: Lucas Hilderbrand, "Sex Out of Sync: Christmas on Earth's and Couch's Queer Sound Tracks", Camera Obscura, 28, no. 2 (2013): 44 -75.

${ }^{15}$ Jonas Mekas, Movie Journal (New York, NY: MacMillan, 1972), pp. 111-2. See here for the story of Rubin fighting the censorship imposed by the Belgian Minister of Culture on the Third International Experimental Film Exposition.

16 Osterweil, Flesh Cinema, 147; David James, Allegories of Cinema (Princeton, NJ: Princeton University Press, 1989).

${ }^{17}$ Craig Fischer, "Her Incantatory Voice: Barbara Rubin and Christmas on Earth", Bright Lights Film Journal (2020): 5-6. Accessed January $20^{\text {th }}, 2022$, https://brightlightsfilm.com/her-incantatory-voicebarbara-rubin-and-christmas-on-earth/\#film.

${ }^{18}$ Fisher, "Her Incantatory Voice", 6; David Tetzlaff, "Re: [Frameworks]: Christmas on Earth: Audio, Randomness, Cinema". Frameworks listserv (2010). Accessed January $20^{\text {th }}, 2022$, http://www.hi-beam.net/fw/fw43/0323.html

${ }^{19}$ Thea Patterson, "Deliverables" in The Go-To How-To Book of Anarchiving, ed. Andrew Murphie (Montreal: The SenseLab, 2016), 51.

${ }^{20}$ Massumi, Brian, "THE PROCESS SEED BANK, THE ANARCHIVE AND SUBTRACTION (Excerpt from a conversation at the Distributing the Insensible event) Erin Manning and Brian Massumi" in The Go-To How-To Book of Anarchiving, ed. Andrew Murphie (Montreal: The SenseLab, 2016), 48.

${ }^{21}$ Gordon Ball, 66 Frames (Minneapolis, MN: Coffee House Press, 1999), 232.

${ }^{22}$ Osterweil, Flesh Cinema, 31.

${ }^{23}$ Daniel Belasco, "The Vanished Prodigy", Art in America (2005), 63.

${ }^{24}$ Sally Banes, Sally Banes, Greenwich Village 1963: Avant-Garde Performances and the Effervescent Body (Durham, NC: Duke University Press, 1993); David James, Allegories of Cinema: American Film in the 1960s (Princeton, NJ: Princeton University Press, 1989).

${ }^{25}$ Osterweil, Flesh Cinema, 34.

${ }^{26}$ Jaques Derrida, “Archive Fever: a Freudian Impression” in diactritics 25, no.2 (1995), 27.

${ }^{27}$ Laura U. Marks, The Skin of the Film: Intercultural Cinema, Embodiment, and the Senses (Durham, NC: Duke University Press, 2000), 132.

${ }^{28}$ Sally Banes, Greenwich Village 1963: Avant-Garde Performances and the Effervescent Body (Durham, NC: Duke University Press, 1993), 224.

${ }^{29}$ Osterweil, Flesh Cinema, 36.

${ }^{30}$ Ara Osterweil, “Absently Enchanted", 139.

${ }^{31}$ James Hoberman, Vulgar Modernism: Writing on Movies and Other Media (Philadelphia, PA: Temple University Press, 1991), 141.

32 Jonas Mekas, "Notes on Some New Movies and Happiness" in Film Culture Reader, ed. Adam P. Sitney (New York, NY: Praeger, 1970), 323.

${ }^{33}$ Derrida, "Archive Fever"; So Mayer, A Nazi Word for a Nazi Thing, 57.

${ }^{34}$ Hito Steyerl, "In Defense of the Poor Image', e-flux, 10 (2009), accessed January 20 2022 https://www.e-flux.com/journal/10/61362/in-defense-of-the-poor-image

${ }^{35}$ Massumi, "Working Principles", 6.

${ }^{36}$ Marks, Skin of the Film, 231.

${ }^{37}$ Andrew Murphie, "Where Are the Other Places? (Archives and Anarchives)" in The Go-To HowTo Book of Anarchiving, ed. Andrew Murphie (Montreal: The SenseLab, 2016), 41.

${ }^{38}$ Murphie, "Where Are the Other Places?", 43.

${ }^{39}$ Laura U. Marks, Touch: Sensuous Theory and Multisensory Media (Minneapolis, MN: Minnesota University Press, 2002), 92. 


\section{Bibliography}

Belasco, Daniel. 'The Vanished Prodigy', Art in America, (January 2005): 61-65.

Ball, Gordon. 66 Frames. Minneapolis, MN: Coffee House Press, 1999.

Banes, Sally. Greenwich Village 1963: Avant-Garde Performance and the Effervescent Body. Durham, NC: Duke University Press, 1993.

Derrida, Jaques. “Archive Fever: A Freudian Impression”. Diactritics, Vol 25, N. 2, (1995): 963.

Fischer, Craig. "Her Incantatory Voice: Barbara Rubin and Christmas on Earth", Bright Lights Film Journal (2020): 5-6. https://brightlightsfilm.com/her-incantatory-voice-barbara$\underline{\text { rubin-and-christmas-on-earth/\#film }}$

James, David. Allegories of Cinema: American Film in the 1960s. Princeton, NJ: Princeton University Press, 1989.

Hilderbrand, Lucas. "Sex Out of Sync: Christmas on Earth's and Couch's Queer Sound Tracks." Camera Obscura, Vol. 28, N. 2, (2013): 44 -75.

Hoberman, James. Vulgar Modernism: Writing on Movies and Other Media. Philadelphia, PA: Temple University Press, 1991.

Marks, Laura U. The Skin of the Film: Intercultural Cinema, Embodiment, and the Senses. Durham, NC: Duke University Press, 2000.

Marks, Laura U. Touch: Sensuous Theory and Multisensory Media. Minneapolis, MN: Minnesota University Press, 2002.

Massumi, Brian. "Working Principles" in The Go-To How-To Book of Anarchiving, ed. Andrew Murphie, 6-7. Montreal: The SenseLab, 2016.

Mayer, So. A Nazi Word for a Nazi Thing. London: Peninsula Press, 2020.

Mekas, Jonas. "Notes on Some New Movies and Happiness" in Film Culture Reader, ed. Adam P. Sitney, 317-325. New York, NY: Praeger, 1970. 
Mekas, Jonas, Movie Journal. New York, NY: MacMillan, 1972.

Muñoz, José Esteban. Cruising Utopian, The Then and There of Queer Futurity. New York: New York University Press, 2009.

Murphie, Andrew. "Where Are the Other Places? (Archives and Anarchives)" in The Go-To How-To Book of Anarchiving, ed. Andrew Murphie, 41-43. Montreal: The SenseLab, 2016.

Osterweil, Ara. “Absently Enchanted: The Apocryphal, Ecstatic Cinema of Barbara Rubin” in Women's Experimental Cinema, ed. by Robin Blaetz. 127-151. Durham, NC: Duke University Press, 2007.

Osterweil, Ara. Flesh Cinema: The Corporeal Turn in American Avant-Garde Film. Manchester: Manchester University Press, 2014.

Patterson, Thea. "Deliverables" in The Go-To How-To Book of Anarchiving, ed. Andrew Murphie, 51. Montreal: The SenseLab, 2016.

Plumb, Leslie. “Immediations Partnership Grant Proposal, 2013”. Leslie Plumb. February 4, 2022. http://leslieplumb.com/webdev-front.html.

Rubin, Barbara. “Co-Op Declaration”. The Barbara Rubin Papers. Division of Rare and Manuscript Collections, Cornell University Library, Ithaca, NY.

Rubin, Barbara. 'Christmas on Earth [Projection Instructions for her film Christmas on Earth, ca. 1965]' in Film Culture 80: The Legend of Barbara Rubin, edited by Jonas Mekas and Chuck Smith, p. 163. Leipzig: Specter Books, 2018.

Steyerl, Hito,'In Defense of the Poor Image', e-flux, 10 (November 2009). https://www.eflux.com/journal/10/61362/in-defense-of-the-poor-image.

Taubin, Amy. 'She Picked up a Camera and Decided to be a Filmmaker. Amy Taubin on Barbara Rubin' in Film Culture 80: The Legend of Barbara Rubin, edited by Jonas Mekas and Chuck Smith, p. 41 -52. Leipzig: Specter Books, 2018. 
Tetzlaff, David. "Re: [Frameworks]: Christmas on Earth: Audio, Randomness, Cinema". Frameworks listserv (2010). http://www.hi-beam.net/fw/fw43/0323.html.

\section{Filmography}

Barbara Rubin and the Exploding NY Underground, Chuck Smith, 2019.

Christmas on Earth, Barbara Rubin, 1963-65.

Flaming Creatures, Jack Smith, 1963.

Scorpio Rising, Kenneth Anger, 1963.

Screen Test [ST286]: Barbara Rubin, Andy Warhol, 1965.

The Velvet Underground, Todd Haynes, 2021.

Walden, Jonas Mekas, 1964-69.

\section{Author Biography}

Giulia Rho is a PhD Candidate and Teaching Associate of the Film Studies Department at Queen Mary University of London (QMUL). Her research investigates the American avantgarde and LA Rebellion, Queer Time, Feminist Phenomenology, and French Feminism. Publications include ‘American Avant-Garde Cinema's Philosophy of the In-Between' in Film Philosophy (upcoming). 